\title{
FEATURE Runaway barges damage Marseilles Lock and Dam during 2013 flood on the Illinois River
}

\author{
Kenneth R. Olson and Lois Wright Morton
}

I

$\mathrm{n}$ the spring of 2013, the highest floodwater levels in the last 70 years were recorded on the Illinois Waterway (NOAA 2013), a $541 \mathrm{~km}$ (336 mi) navigation system of rivers, lakes, and canals running from Lake Michigan (Chicago, Illinois) to the mouth of the Illinois River at Grafton, Illinois, on the Mississippi River (figure 1). River traffic, made possible by eight lock and dam structures on the waterway, was halted when the dam at Marseilles, 247 river miles above the Mississippi River, was damaged. On April 19, 2013, the currents and winds on the Marseilles pool above the dam caused seven barges to break free and crash into the Marseilles Dam. Four of the barges sank (figure 2). These barges blocked the southernmost spillway submersible tainter gates used to maintain the $2.7 \mathrm{~m}(9 \mathrm{ft})$ navigation channel and prevented gate adjustments to release excess water from the pool. Floodwaters backed up for many kilometers and flooded adjacent Illinois River bottomlands, including the town of Marseilles (figure 3). Approximately 1,500 residents were evacuated from the low-lying areas, and more than a meter (3 ft) of floodwater surrounded 200 homes and building structures and destroyed at least 24 homes. Many other buildings required substantial repairs, and a large number of appliances and household furnishings had to be discarded. When the rains stopped and upstream runoff slowed, flood waters in Marseilles drained out through a diversion channel previously used by a former hydroelectric plant.

There was an immediate and substantial federal disaster relief response including Federal Emergency Management Agency (FEMA), Lutheran Early Response, and Team Rubicon workers. Damages were in the millions of dollars, and many residents and relief workers were housed in area

Kenneth R. Olson is professor of soil science in the College of Agricultural, Consumer, and Environmental Sciences, University of Illinois, Urbana, Illinois. Lois Wright Morton is professor of sociology in the College of Agriculture and Life Sciences, lowa State University, Ames, lowa.

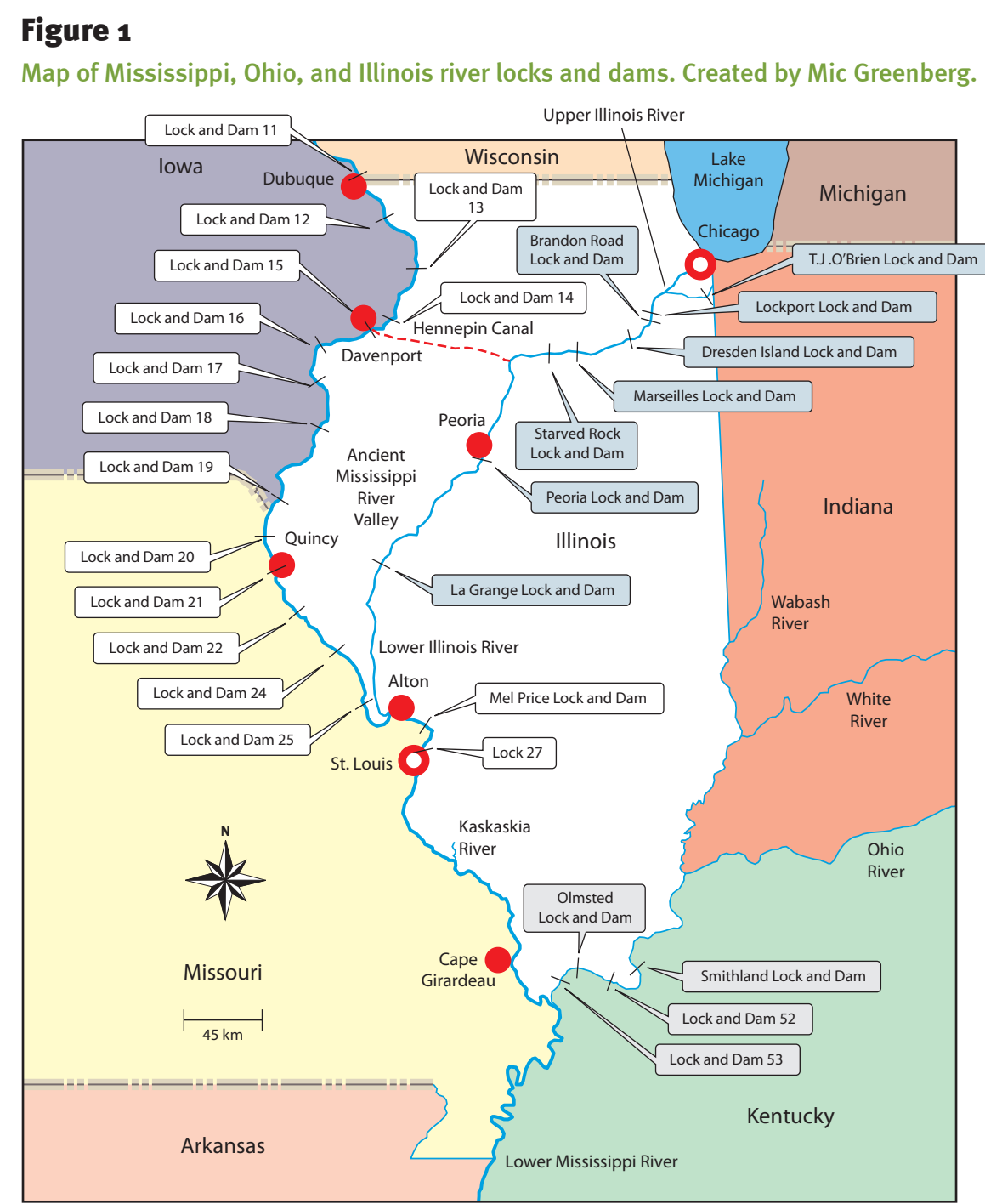

Legend

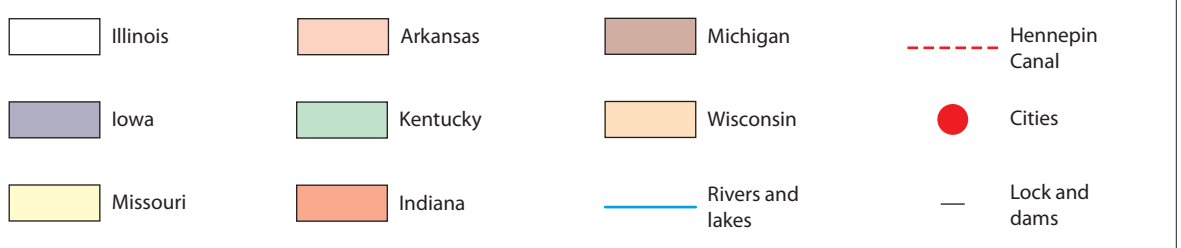

hotels for weeks. The barge accident and 2013 flooding of Marseilles did some damage to park lands (figure 4), sidewalks, and roads. The greatest agricultural impact was the suspension of the shipping of fertilizers and grains. The primary objective of this study is to document the damages to the dam structure, which reduced the capacity to manage the Marseilles water pool for navigation on the Illinois Waterway and to limit flooding in the town of Marseilles.

\section{PARTIAL USE OF ANCIENT MISSISSIPPI RIVER CHANNEL BY ILLINOIS RIVER}

The backbone of the Illinois Waterway is the Illinois River, which partially runs through the ancient Mississippi River Valley (figure 1) toward St. Louis, Missouri. 


\section{Figure 2}

Seven partially sunken barges at the Marseilles Lock and Dam and deflectors. Photo courtesy of Major General John W. Peabody, commander of the Mississippi Valley Division, US Army Corps of Engineers, and president of the Mississippi River Commission.

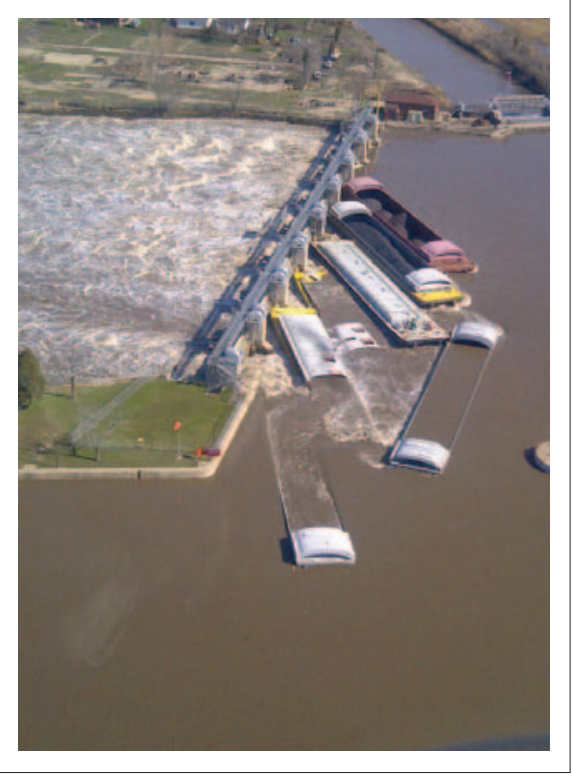

Historically the ancient Mississippi River entered Illinois to the south of Davenport, Iowa, and flowed east into the valley where the Hennepin Canal is located. The Wisconsin glacier and end moraine blocked the flow of the ancient Mississippi River through the valley approximately 15,000 to 30,000 years ago. The upper Illinois River headwaters now start near Chicago, Illinois, and outlets to the Mississippi River are located at Grafton, Illinois. Had the Wisconsin glacier advance not plugged the ancient Mississippi River Valley and caused the realignment to its current location, the land area south of Hennepin Canal, west of current Illinois River, and north of Alton, Illinois, would probably belong to the states of Iowa and Missouri. This assumes the Mississippi River would have remained the western boundary of Illinois. This area is approximately one-seventh of Illinois land area, or about 2,000,000 ha $(5,000,000 \mathrm{ac})$ in size, and would have dramatically changed the shape of Illinois.

\section{Figure 3}

Map of the Illinois River bottomlands and adjacent upland between the Marseilles Lock and the Marseilles Dam. Created by Mic Greenberg.

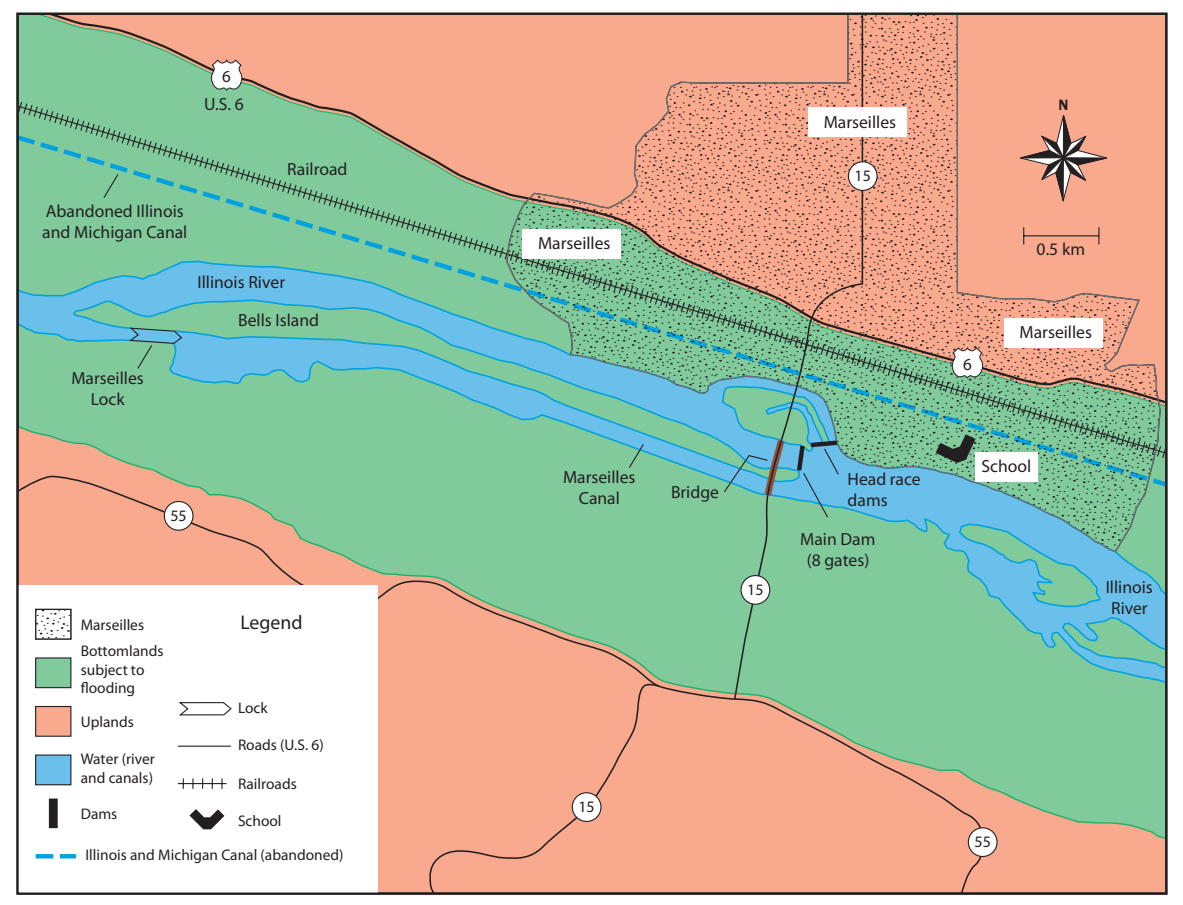

\section{CONSTRUCTING THE ILLINOIS WATERWAY SYSTEM}

The United States has more than 25,000 mi $(40,000 \mathrm{~km})$ of navigable inland waterways with the Mississippi River system accounting for almost 9,000 $\mathrm{mi}(14,400$ $\mathrm{km})$. Many of these inland waterways are only navigable because of extensive lock and dam engineering. The map of the Upper Mississippi River Basin (figure 1) shows the locks and dams on the sections of the Mississippi and Ohio rivers that border Illinois and those on the Illinois River within the state of Illinois. The Illinois Waterway runs from the Calumet River in Chicago to Grafton, Illinois, where the Illinois River flows into the Mississippi River connecting the Great Lakes to the Gulf of Mexico. The construction in 1900 of the Chicago Sanitary and Ship Canal and the reversing of the Chicago River to flow out of rather than into Lake Michigan made this waterway a major route for shipping goods to flow to international markets from the port of New Orleans at the mouth of the Mississippi River (Weeks 2008). The Illinois Waterway drops from $176 \mathrm{~m}$ (578 ft) above sea level at Lake Michigan to $128 \mathrm{~m}(419 \mathrm{ft})$ at the mouth of the Illinois River as it flows southwest into the Mississippi River (figure 1). A system of eight locks on the Illinois River managed by the US Army Corps of Engineers (USACE) controls water flow along the $541 \mathrm{~km}$ (336 mi) system to assure a $2.7 \mathrm{~m}$ (9 ft) deep navigation channel.

A lock is an engineered structure used to raise and lower boats between stretches of water that are at different levels on canals or rivers or to bypass rapids or mill weirs using the water for hydroelectricity (Nelson 1983). It is a chamber with watertight doors or gates at each end that seal off the chamber from the stretch of water between the next upstream or downstream lock. The chamber holds one or more vessels and when full of water lifts the boats to the level of the upstream body of water; when empty, the gate is open to the downstream body of water. The lock and dam system is like a flight of stairs going up and down the river using gravity to move the water and maintain a minimum depth for boat traffic. Water drains from an open lock by gravity into a second 
lock until the water is level. Then barges and boats at the downstream lock can travel upstream to the next lock assured of sufficient water depth for navigation and without expending a great deal of energy against the flow of the river. Once the vessels reach the next lock, they are lifted up the river in a repeating process.

Dams upstream from each lock control the amount of water released or held back to maintain the desired water depth for navigation (e.g., $2.7 \mathrm{~m}$ [9ft] in the case of the Illinois Waterway). Dam capacity to hold the pool of water within each lock to tight tolerances is critical to avoid water levels that are too low for navigation or too high, resulting in flooding along sections of the river with low-lying bottomlands that have been developed.

\section{NAVIGATION ON THE ILLINOIS WATERWAY}

Many different kinds of vessels are used on rivers to move people and products. Navigation was extremely important for foreign and domestic trade and travel in the early days of the United States before cars, trucks, trains, and airplanes were invented. Historically, rivers like the Illinois were used as "roads" to connect inland settlements to river and coastal ports (USACE 2012).

Communities established at these commercial ports, such as Chicago, Illinois, and St. Louis, Missouri, became important economic, cultural, and social hubs in the development of the state of Illinois and were instrumental in unifying the United States as a nation. Many food products and materials are still transported by vessels on the Illinois River and through the Hennepin Canal. Towboats push barges loaded with products, such as grain, coal and petroleum, up and down the Illinois River to loading and unloading facilities.

The most common method of transporting products on rivers is by tow, which consists of one towboat and one or more barges. There are four basic types of barges (USACE 2012). Covered dry cargo barges, such as the ones that crashed into the Marseilles Dam in 2013, carry bulky solid cargo (e.g., dry cement; fertilizers; and farm products, such as corn [Zea mays L.], wheat [Triticum aestivum L.], and soybeans [Glycine max L.]) that need protection

\section{Figure 4}

Stream bank erosion at Illini State Park.

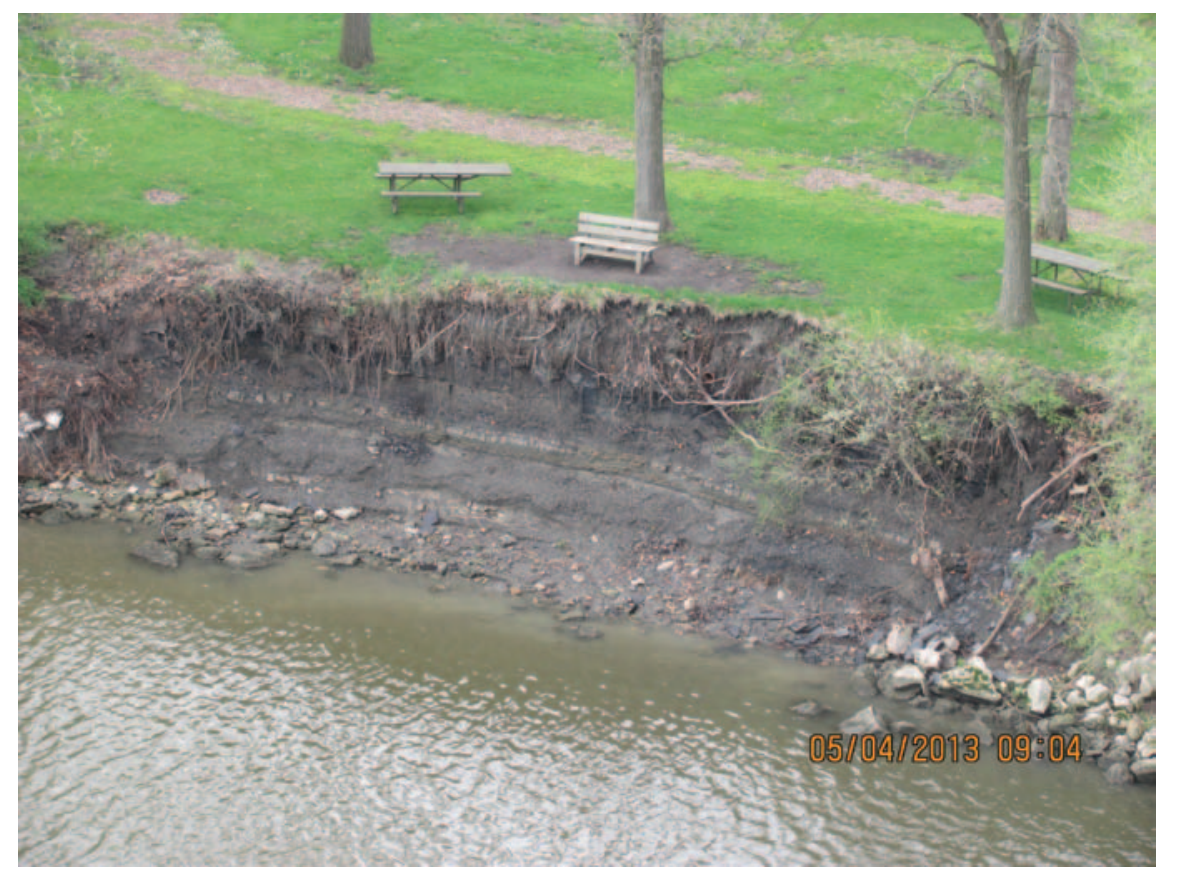

from the weather. Open hopper barges, hold bulky products (e.g., sand, gravel, and coal) that do not need protection from the weather. Liquid cargo (tank) barges carry liquid products such as chemicals, petroleum, oil, and molasses. The fourth type is a deck barge, which carries almost any kind of equipment, materials, or products that can be tied down and do not need protection from the weather.

\section{RECREATION ON THE RIVER}

The Illinois Waterway created water surfaces ideally suited for water-associated recreational activities. In addition to the deep navigation channel, the dams (figure 1) on the Illinois River create a series of eight lakes or pools as well as extensive marshes, swamps, open sloughs, backwater sloughs, ponds, small lakes, and expanses of open water that provide a variety of natural habitats (USACE 2012). Many public and private recreational areas and marinas provide facilities for picnicking, swimming, boat launching, and camping along the Illinois River. Wildlife-oriented recreation includes fishing and opportunities to observe nesting and hatching areas for waterfowl and breeding grounds for aquatic furbearing mammals (Olson and Morton 2014a). The riparian floodplain forest (Olson and Morton 2012) provides habitat for a wide variety of animals.

\section{MARSEILLES LOCK AND DAM}

The eight locks and dams on the Illinois River were designed by the USACE to function as a unit to maintain the shipping channel and other types of water traffic (figure 1). The Marseilles Lock and Dam system is located upriver about 8 river miles from Starved Rock Lock and Dam. The Marseilles Lock at 244.6 mile marker is $4 \mathrm{~km}(2.4 \mathrm{mi})$ west and downstream from the Marseilles Dam located at the City of Marseilles (figure 3). The dam at mile marker 247, constructed in 1933 to maintain the navigation pool between Marseilles and Dresden Island locks, lies adjacent to the upstream end of the Marseilles Canal, which was created as a bypass to the rapids used to generate hydroelectric power (Cooper et al. 2001). Thus, the Illinois River at Marseilles splits into three channels (figure 3): Marseilles Canal, which flows directly into Marseilles Lock; the rapids with water flow controlled by the dam; and the manmade channel on the Marseilles side of the river that runs through the former hydroelectric plant. The location of the abandoned IllinoisMichigan Canal is shown in figure 3. 
The dam at Marseilles is a gated structure with eight $18.3 \mathrm{~m}(60 \mathrm{ft})$ wide submersible tainter gates (figure 2), which cover a total width of $168.2 \mathrm{~m}(552 \mathrm{ft})$, and a $14.2 \mathrm{~m}$ (46.5 ft) section containing an abandoned ice chute (Cooper et al. 2001). The main dam has a normal head about 4.m (13 ft) and maintains an upper pool at an elevation of $147.3 \mathrm{~m}$ (483.2 ft) (Cooper et al. 2001). The submersible tainter gates $(4.9 \mathrm{~m}$ [16 ft] high with a radius of 7.6 $\mathrm{m}[25 \mathrm{ft}]$ ) are used as a spillway and are frequently adjusted to maintain the 2.7 $\mathrm{m}$ (9 ft) navigation channel and to prevent overtopping when the gates are fully closed. The gates are remotely operated (with manual capability) using a schedule that (1) maintains a flat pool, (2) prevents excessive scouring (e.g., one gate wide open while remaining gates are closed), (3) varies to reduce vulnerability to floating ice and debris, (4) minimizes out-draft, and (5) assures approximate equal use of the gates (Cooper et al. 2001). During flooding conditions, the gate schedule attempts to manage the high discharge created from wide-open gates and the considerable turbulence below the spillway, which has high potential for downstream scouring.

\section{FLOODING ON THE ILLINOIS RIVER}

The record flooding on the Illinois River in spring of 2013 raised the pool levels behind the dams along the Illinois River. Heavy rain and runoff from tributaries along with strong winds created river currents and conditions that made it difficult to secure the barges being moved in the shipping channel or anchored along the channel. Seven unmoored barges were caught in the currents of the Marseilles pool and struck and damaged five of the eight tainter gates at the dam leaving two gates with 5 to $6 \mathrm{~m}$ (16 to $20 \mathrm{ft}$ ) holes (Plume 2013). Four of the seven barges partially sunk in front of the southern gates (figure 2) and the other three barges blocked the water flow through three middle gates (figure 5) on April 19, 2013. As a result, the blocked gates were unable to fully open to release the additional floodwaters. Water backed up into the Marseilles pool, topped river banks with and without a low levee protection, and flooded the bottomlands with alluvial soils (Sawmill, Millesdale, DuPage, Lawson, and Benton soils) in the town of Marseilles (figure 3). Most of these poorly drained soils were developed under prairie and in alluvium over outwash or limestone. The floodwaters also flowed into the third channel running through the City of Marseilles, the old diversion previously used to generate hydroelectric power, and then back into the Illinois River west of the Marseilles Dam.
More than 200 homes, a school, and public buildings were flood damaged. Floodwaters reached depths of $1 \mathrm{~m}$ (3.3 $\mathrm{ft}$ ) in many buildings, and the lower onethird of the walls had to be removed and replaced. In the weeks immediately after the barge accident, hundreds of relief workers (figure 6), including FEMA, Lutheran

\section{Figure 5}

Partially sunken barge and damaged tainter gates stuck at different heights.

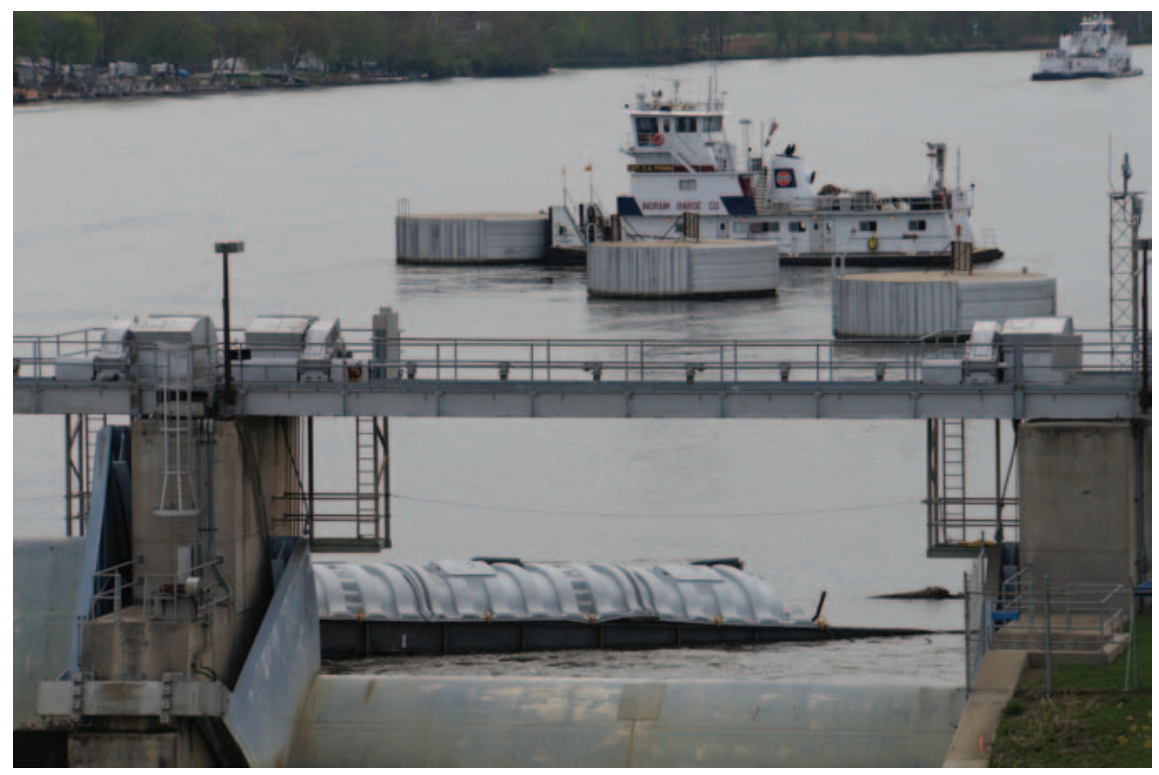

\section{Figure 6}

Relief workers removing damage items from flooded homes.

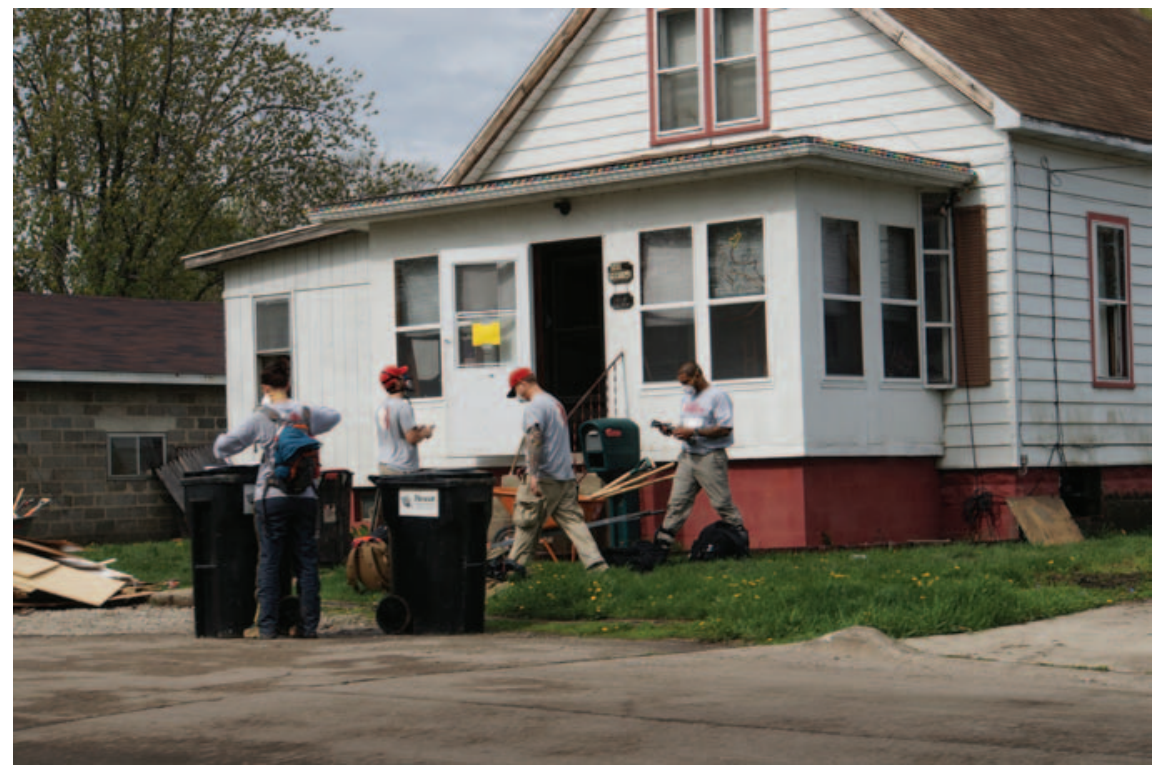


Early Response, and Rubicon teams, aided residents, helped remove the damaged appliances and household items, or inspected the properties to assess the extent of the damage. The response teams helped clear out flood debris, damaged appliances, and furniture; removed walls and cabinetry; and even treated the houses for mold. Dumpsters and port-a-potties were brought in for use by some residents and by relief workers. The damaged appliances were placed out on the streets, put in dumpsters, or hauled to a public parking lot where relief workers sorted damaged property into categories and hauled the damaged household items away. Long-time residents - including some that had lived there for 45 to 65 yearsreported they had never experienced this kind of flooding before.

The Marseilles Elementary District 150, which serves 632 students, sued the Ingram Barge Company for US\$6.4 million for flood damages (Stout 2013). By June 30, 2013, 40 Marseilles property owners also filed claims against Ingram with more claims expected. The school claim was filed in the Chicago federal court, and lawyers argued that the Nashville-based company "breached its duty" to safely secure the barges and was at fault for massive flooding of the city. The damage to the school was mostly covered by insurance from Illinois School District Agency, through a self-insured pool of several school districts, except for a US\$834,000 deductible. To hold Ingram legally and financially responsible, it was necessary for the school district to file the claim. The lawsuit claims Ingram "had a duty to operate its vessels safely and to secure its barges under tow to prevent against a break away." School district lawyers claimed that because of the breakaway and resulting crash, "the flow of the Illinois River was impeded and altered such that floodwater flowed ashore, causing extensive flood damages to the Marseilles Elementary School" (Stout 2013).

In anticipation of damage suits, Ingram filed for protection in federal court in May of 2013, asking it be freed from liability for the flood damage or at least be restricted to the value of the seven barges and towboat, or US\$4.2 million. Ingram Senior Vice President Dan Mechlenborg said the company does not believe it was respon- sible for the flooding of Marseilles and the school district. The record flooding could have resulted in the flooding of Marseilles on or after April 18, and evacuation notices were issued before the Marseilles Dam accident occurred. When the record high flood peak was predicted to occur on the evening of April 18, police began notifying and evacuating 1,500 residents from low-lying sections of Marseilles (figure 3). Some residents were disabled and bedridden and had to be moved along with medical equipment. Many lost everything in homes that were touched by floodwaters. The USACE is investigating to determine if all or part of the flooding was as a result of the seven barges slamming into the Marseilles Dam (figure 2).

\section{DAMAGES TO MARSEILLES LOCK AND DAM AND BARGE REMOVAL BY US ARMY CORPS OF ENGINEERS}

The three barges that were floating in front of the dam were removed within a few days of the accident. The partially sunken barges were removed by cranes (figure 5) after the Marseilles pool was lowered for dam repairs. Salvage operations were led by Unified Command and continued for weeks after the barge accident. An additional crane was brought in on April 26, 2013, to off-load cargo from the sunken barges. The removed cargo was placed in a receiver barge during the next two days. After enough of the cargo was unloaded, the barges were refloated and removed.

USACE monitored the dam the first few weeks after the barge incident to determine if significant damage to the dam had occurred. If there was serious damage, it would have posed a threat to the structure and to safety of the public. Due to high river levels and interference by sunken barges, the most critical public safety damage is scouring of the riverbed (USACE 2013). Abnormal or accelerated scouring could undercut the dam's foundation and result in catastrophic failure at some future point in time. In early June of 2013, heavy rains in the local watershed resulted in rapid discharge of floodwaters through the four gates on the north side of the river and had the potential of accelerated scouring on the bottom of the riverbed and on the north side of the river bank, which is par- tially protected by a cement floodwall. The USACE spent much of the spring of 2013 assessing the dam safety. If failure of the dam were to occur, many commercial vessels, recreational craft, and river-based structures could be damaged by the receding pool. In addition, river structures below the dam could be impacted by debris. However, dam failure would not have caused widespread downstream flooding since the Marseilles Dam is not a flood control structure and does not retain water like a reservoir.

\section{LOCK AND DAM REPAIRS}

The USACE created a temporary rock dike dam (figure 7) during the four weeks after the accident to permit repairs to the three most severely damaged gates. The temporary U-shaped dike downstream from the three gates included a series of culverts to hold or release water from the pond as needed, substituting for the controlled spillway effect under normal conditions. The temporary dike was able to hold enough water to elevate the navigation pool by late May 15, 2013, in order to restore boat traffic. However, another storm system in late May and early June of 2013 flooded the watershed and raised the discharge rate through the four open gates and complicated the dam repair. The Marseilles Phase 1 repair costs are US $\$ 10$ million. The current cost estimate to complete Phase II repairs ranges from US $\$ 30$ to US\$50 million for a total of US $\$ 40$ to US $\$ 60$ million. The money comes from the Emergency Response or Disaster funds available to USACE.

\section{SHUTDOWN OF SHIPPING AND BOATING ON ILLINOIS RIVER}

In addition to developing and maintaining structures that protect agricultural, residential, and commercial lands along the Illinois River as well as the Ohio and Mississippi rivers, the USACE is also charged with maintaining a river channel

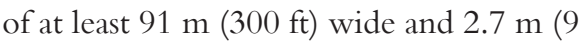
$\mathrm{ft}$ ) in depth for river barge traffic (Olson and Morton 2014b). The decision to lower the Marseilles pool for dam repairs resulted in suspension of all use of the pool for shipping and travel. The northern stretch of Illinois River, a main artery for shipping bulk commodities to terminals at the Gulf 


\section{Figure 7}

Temporary dike and pond created below the three damaged gates on the Marseilles Dam.

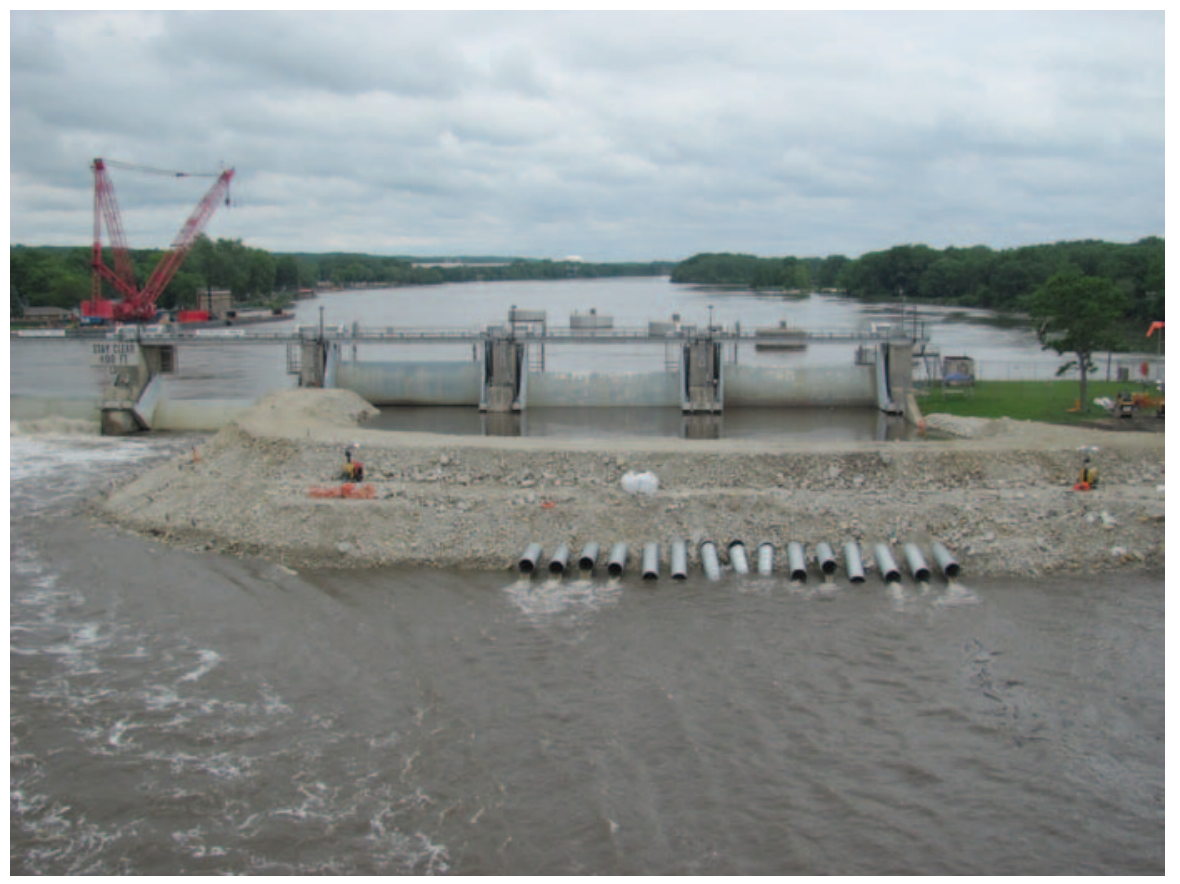

of Mexico, was affected. Both agricultural inputs, such as fertilizer and lime material, and outputs, including grain, are shipped using the Illinois River shipping channel. The torrential rains that moved through the upper Midwest in April and May of 2013 resulted in the Coast Guard declaring the Illinois River unnavigable; any transport required Coast Guard permission. A safety zone was created in order to protect salvage operations from impediment by the vessel traffic above the damaged Marseilles Dam. The safety zone extended between the Marseilles Lock and Dam and Seneca, Illinois. An additional section between Alton, Illinois, and Brendon Road lock at Joliet remained closed for weeks due to high water and excessive river debris. USACE maintained a $2.7 \mathrm{~m}$ (9 ft) navigational channel between Marseilles and the Dresden dams between April 27 and May 7, 2013. Heavy rains in late May extended the shipping restrictions.

\section{CONCLUSIONS}

The Illinois Waterway continues to be an essential transportation corridor for moving goods from the Great Lakes to St. Louis, Missouri, and the port of New Orleans,
Louisiana. Unpredictable weather and extreme rain events can cause hard-tocontrol flooding and river currents which can damage river vessels, waterway control structures, and communities along the river. Damage to the Marseilles Dam when seven unsecured Ingram barges crashed into the dam and damaged the tainter gates affected navigation and put at risk the adjacent community. The USACE is still assessing whether the barge accident caused or enhanced the flooding in Marseilles and damaged the elementary school and the local residences. Many federal, state, and private relief agencies responded to help assess and clean up the damage from flooding, and USACE began repairing the damaged Marseilles Dam structure in summer of 2013. This was done in an effort to open the shipping channel, which is one of the most used in the nation.

\section{ACKNOWLEDGEMENTS}

Partial funding for this research was provided by the Iowa Agriculture and Home Economics Experiment Station, College of Agriculture and Life Sciences at Iowa State University. Additional funding support comes from National Great Rivers Research and Education Center, Regional Research Project
No. 15-354 (Erosion-Productivity) and in cooperation with North-Central Regional Project 15-372 (NCERA-3) Soil Survey. It is published with funding support from the Director of the Illinois Office of Research, College of Agricultural, Consumer, and Environmental Sciences, University of Illinois, Urbana, Illinois.

\section{REFERENCES}

Cooper, D.R., T.L. Fagerburg, T.N. Waller, S.W. Guy, and A. Tuthill. 2001. Monitoring of Marseilles Dam submersible gates, Illinois River, Illinois. Engineer Research and Development Center ERDC TR-01-15. Washington, DC: US Army Corps of Engineers.

Nelson, S.B. 1983. Water engineering. In Standard Handbook for Civil Engineers, ed. F.S. Merritt. New York: McGraw-Hill.

NOAA (National Oceanic Atmosphere Administration). 2013. Historic crests. Morris, IL: National Weather Service, Advanced Hydrologic Prediction Service.

Olson, K.R., and L.W. Morton. 2012. The effects of 2011 Ohio and Mississippi River valley flooding on Cairo, Illinois, area. Journal of Soil and Water Conservation 67(2):42A-46A, doi:10.2489/ jswc.67.2.42A.

Olson, K.R., and L.W. Morton. 2014a. The 2011 Ohio River Flooding of the Cache River Valley in Southern Illinois. Journal of Soil and Water Conservation 69(1):5A-10 A, doi:10.2489/ jswc.69.1.5A.

Olson, K.R., and L.W. Morton. 2014b. Dredging of the fractured bedrock lined Mississippi River channel at Thebes, Illinois. Journal of Soil and Water Conservation 69(2):31A-35A, doi:10.2489/jswc.69.2.31A.

Plume, K. 2013. Damaged Illinois River lock may hinder barges for weeks. Reuters, April 25, 2013.

Stout, S. 2013. Marseilles Elementary seeks millions from barge company. Ottawa Daily Times, June 25, 2013.

USACE (US Army Corps of Engineers). 2012. The Upper Mississippi River. Nine-foot channel navigation project. Washington, DC: US Army Corps of Engineers.

USACE. 2013. Salvage operations on remaining barges continue. April 27, 2013. Washington, DC: US Army Corps of Engineers.

Weeks, J.A. 2008. The Bridges and Structures of the Illinois River. Highways, Byways, and Bridge Photography. First ed., July 2008. http://www. johnweeks.com/river_illinois/index.html. 